ISSN:

Print - 2277- 078X

Online - $2315-747 \mathrm{X}$

(๖) FUNAAB 2018

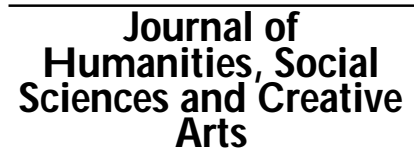

\title{
VALUE CHAIN ANALYSIS OF CASSAVA PRODUCTS IN OGUN STATE, NIGERIA
}

\author{
*V. A. ELEGBEDE, A.O. DIPEOLU AND A.M. SHITTU \\ Department of Agricultural Economics and Farm Management \\ Federal University of Agriculture, Abeokuta, Nigeria. \\ *Comesponding Author: asikavivian@ gmail.com Tel: +2348060156956
}

\begin{abstract}
This study investigated the value chain analysis of cassava products in Ogun State Nigeria. Multistage was used to select 180 cassava processors and marketers. Socio-economic data were obtained from respondents with the use of pre-tested questionnaire. Data were analysed using descriptive statistics, budgetary technique and Analysis of variance (ANOVA). The study revealed that majority ( $84.3 \%$ and $52.8 \%$ ) of Cassava peel processors and marketers were female. In addition, $60.2 \%$ of the processors have secondary education while $51.4 \%$ of the marketers also have secondary education. The value chain activities carried out by the processors were, Gari; harvesting, transportation, peeling, fetching, grating mill, sieving, toasting/drying and packaging. Fufu; harvesting, transportation, peeling, fetching, soaking, sieving and packaging. Lafun; harvesting, transportation, peeling, washing, fetching, soaking, slicing, grating mill, sieving, drying and packaging. The marketing activities includes; transportation, bagging and storage (Elegbede, et al., 2018) while marketers transported, packaged and put products in storage for future sales. The mean gross margin for gari, fufu and lafun processors and marketers along the chain were $\mathrm{N} 35876.13, \mathrm{~N} 120463.61$ and $\mathrm{N} 48098.72$ respectively per annum while net farm income was estimated as N35477.85, N115259.44 and N48098.72. Also, the marketing margin for gari, fufu and lafun was estimated as N25273.07, N2982.65 and N21453.49 respectively per annum while the net marketing margin per annum was estimated as N18766.84, N22489.30 and N16203.81 respectively. Conversely, the marketing efficiency for the cassava products and by-products was estimated as $74.26 \%, 75.44 \%$ and $75.53 \%$ respectively for gari, fufu and lafu with lafu having the highest marketing efficiency when compared with the other cassava products (gari and fufu). From the results of the net farm income and marketing margin, it was discovered that fufu is more profitable along the cassava product value chain when compared to the other products (gari and lafu). This study therefore recommends that processing and marketing of lafun and fufu is efficient and their trade is profitable. Also, cassava processors and marketers should form cooperative groups to increase access to credit for higher output and trade of products.
\end{abstract}

Keywords: cassava products, value chain, marketers, gross margin, processors, marketing efficiency

INTRODUCTION

Cassava (Maniht eadenta Crantz) is a staple food for over 600 million people in large parts of sub - Saharan Africa, South America and Asia. More than half of the world's cassava is produced in Africa, where it is a cheap and major source of calories for over $40 \%$ of the population (Arthur $\&$ al., 2009). The crop is efficient in production of carbohydrates and is adapted to a wide range of environments. The crop is preferred by most resource-constrained farmers because of its 
low input requirements, tolerance to low rainfall and poor soils and ease of propagation by use of vegetative stem cuttings. Cassava roots also constitute an important source of employment and income in rural (often in marginal) areas, and for women as these people process cassava roots into products like gari, lafun, or fufu etc, to sell in their local markets and communities. The major challenge facing Nigeria, the most populous nation in sub-Saharan Africa after the consolidation of her democratic rule is the revitalization of her economy and the improvement of the livelihoods of its citizens, two-thirds of whom are poor - IITA (2005).

Nigeria is the largest producer of cassava in the world with over 34 million tons produced in 2007 (FAO 2007 in Lenis, et al (2009)). However, most of what is produced is consumed locally, with over 20 percent of the harvested produce wasted due to production and post harvest inefficiencies (Ezedinma et al. 2007 in Lenis, et al (2009)). To them, if these inefficiencies are addressed alongside the current development of improved varieties of cassava coupled with an associated yield increase, Nigeria could take advantage of the increased national and international market opportunities around the globe. To Odedina et al (2009), suggested that the need to increase food production should always be a priority in Africa. To feed the ever increasing urban population, food supply from every farm household has to increase by at least $63 \%$ in 10 years (Sanni et al., 2009). Cassava is a food security crop (Nweke, 2003) because of its ability to grow under a wide range of conditions, some of which are quite unsuitable for other crops.

D espite this role of cassava in the Nigerian economy, there is need to increase the value addition mechanism by improving the quality of cassava products in Nigeria. Processing predominantly at small scale, employing little or no mechanization, resulting in an inability to meet the quality and quantity demand of the industry and other users of the product. Prominent among other factors are; high post harvest losses and low export of cassava products, (Onwulalu, 2007).

A value chain can be defined as the full range of activities which are required to bring a product or service from conception, through the different phases of production (involving a combination of physical transformation and the input of various producer services), delivery to final consumers, and final disposal after use (Elegbede, $\notin$ al., 2018). Value chain activities of cassava products begins with the processing activities which includes $\mathrm{G}$ ari; harvesting, transportation, peeling, washing, fetching, grating mill, sieving, toasting and packaging. Fufu; harvesting, transportation, peeling, washing, fetching, soaking, sieving and packaging. Lafun; harvesting, transportation, peeling, washing, fetching, soaking, slicing, grating mill, sieving, drying and packaging. The marketing activities includes; transportation, bagging, storage for future sales (E legbede, $\notin \mathrm{al}$., 2018).

This article examines the value chain of cassava products in Ogun State Nigeria. Descriptive statistics, budgetary technique and a t-test were used to describe the socioeconomic characteristics of cassava processors and marketers, estimate the financial outcome and profitability in value chain of cassava peels and test the significant difference between the profit levels of cassava chain actors in $\mathrm{O}$ gun State Nigeria. 


\section{METHODOLOGY \\ The Study Area}

O gun state is located in the south - western Nigeria. It is located within latitudes $3030^{\prime} \mathrm{N}$ - 4030' $\mathrm{N}$ and longitudes $6030^{\prime} \mathrm{E}-7030 \mathrm{E}$. The state has 20 Local Government Areas. Ogun State is bounded in the west by the republic of Benin, in the south by Lagos State and the Alantic 0 cean, in the east by Ondo State and in the North by Oyo State. Ogun State covers a land area of 16,762 square kilometres with a population of 3,728,098 (Ogun State Annual Report, 2000).

\section{Method of Data Collection}

Primary data was collected through structured questionnaire administered to cassava processors and marketers. Multistage random sampling technique was used to select 180 cassava based processors and marketers in the study area. This involved four stages, the first stage, involved the selection of two zones from the four zones of the Ogun State Agricultural Development project (OGADEP) namely Abeokuta and Ijebu zones. This was done because of the predominance of cassava based farming and processing in these zones.

(Elegbede, $\mathrm{e} a \mathrm{al}$, 2018). In the second stage, six blocks were proportionately selected from the two zones; three blocks each from the 2 zones. Next, simple random sampling of two cells from each block with a total of twelve cells. Finally, a random selection of nine processors and six marketers from each cell resulting in a total of 180 respondents.

\section{Methods of $D$ ata Analysis}

Data was analysed using descriptive statistics, budgetary technique, and t-test of difference of means between the profit level of the respondents. The gross margin analysis was used to determine the profitability of processing and marketing cassava products. The difference of mean analysis was done to test the significance difference between the profit levels of cassava processors and marketers in O gun State Nigeria. D etailed specifications of the theoretical framework are common in literature (Olukosi and Erhabor, 1988).

\section{Gross Margin Analysis}

The gross margin for an average processor and marketer of cassava peel was calculated and compared as the difference between the total revenue and total variable cost. The mathematical equation is given below;

$$
G M_{i}=T R_{i}=T V C_{i}
$$

Where $i$ is the number of processors and marketers from $i . . . . . . n$

$G M_{i}=$ Gross margin realized from the ith processor and marketer of cassava products

$T V C_{i}=$ Total variable cost

$T R_{i}=$ Total revenue

$T R_{i}=P_{i} Q_{i}$

$P_{i}=$ price per unit of output $(\mathrm{N})$

$Q_{i}=$ Output (kg)

$N P=G M_{i}=T R_{i}=T C_{i}$

Where, ${ }^{N P}=$ Net profit

\section{Depreciation}

The straight line depreciation method was used to calculate the depreciation cost of the equipments (fixed assets such as baskets, trays, bags sieves etc.) used in cassava prod- 
ucts processing and marketing in the study Measures of financial outcome area.

The returns per naira invested and operating

Annual depreciation $=\frac{P p-S}{n}$

Where $P p=$ purchase price, $\mathrm{S}=$ Salvage value, $n=$ no of years of useful life of the asset. ratios were used to determine and compare the measure of financial outcome of the cassava peels processors and marketers in the study area. They were calculated using the formula below:

Returns per naira invested which is ${ }^{\frac{T R i}{T C i}}=\frac{\text { Total revenue }}{\text { total cost }}$

Operating ratio which is $\frac{T C i}{T R i}=\frac{T \text { total cost }}{\text { total revenue }}$

All these determine the profitability and financial level of production.

\section{Marketing $M$ argin and $E$ fficiency}

Marketing margin is a measure of differences between price paid by the consumer of a good and the price paid by the producer or seller of the goods. In this study, marketing margin was determined by the difference between the purchase price and the selling price of the products. The marketing margin is computed thus:

\section{MM = Selling Price (Sp) - Purchase} Price (Pp)

Where, $\mathrm{MM}=$ Marketing Margin

The major drawback to this method of the analysis is in the non- indication of the point of profit maximization and neglect of fixed costs (Minkalla, 1998)

Ho: $\mu_{(g m m g)}=\mu_{(g m m f)}=\mu_{(g m m l)}$

$\mathrm{H}_{\mathrm{A}}: \mu_{(\mathrm{gmmg})} \neq \mu_{(\mathrm{gmmf})} \neq \mu_{(\mathrm{gmml})}$

Where;

$\mathrm{H}_{0}=$ Null hypothesis

$\mathrm{H}_{\mathrm{A}}=$ Alternative hypothesis

$\mu_{(g m m g)}=$ mean gross margin/ (Naira) in G ari
Marketing efficiency is the ratio of value addition for the goods to their marketing cost (Shepherd, 1965). The value added is the difference between the costs of goods purchased by a firm and price for which it sells those goods (Khols and Uhl, 1967).
V a l u e Added ( V ) = marketing margin-marketing cost

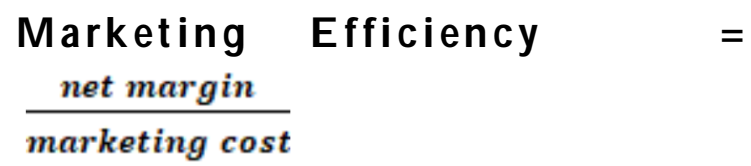

Analysis of Variance (Anova) The ANOVA test was used to test and compare the significance of the differences in the gross margin of the cassava processors and marketers engaged in gari, lafun and fufu in the study area. 


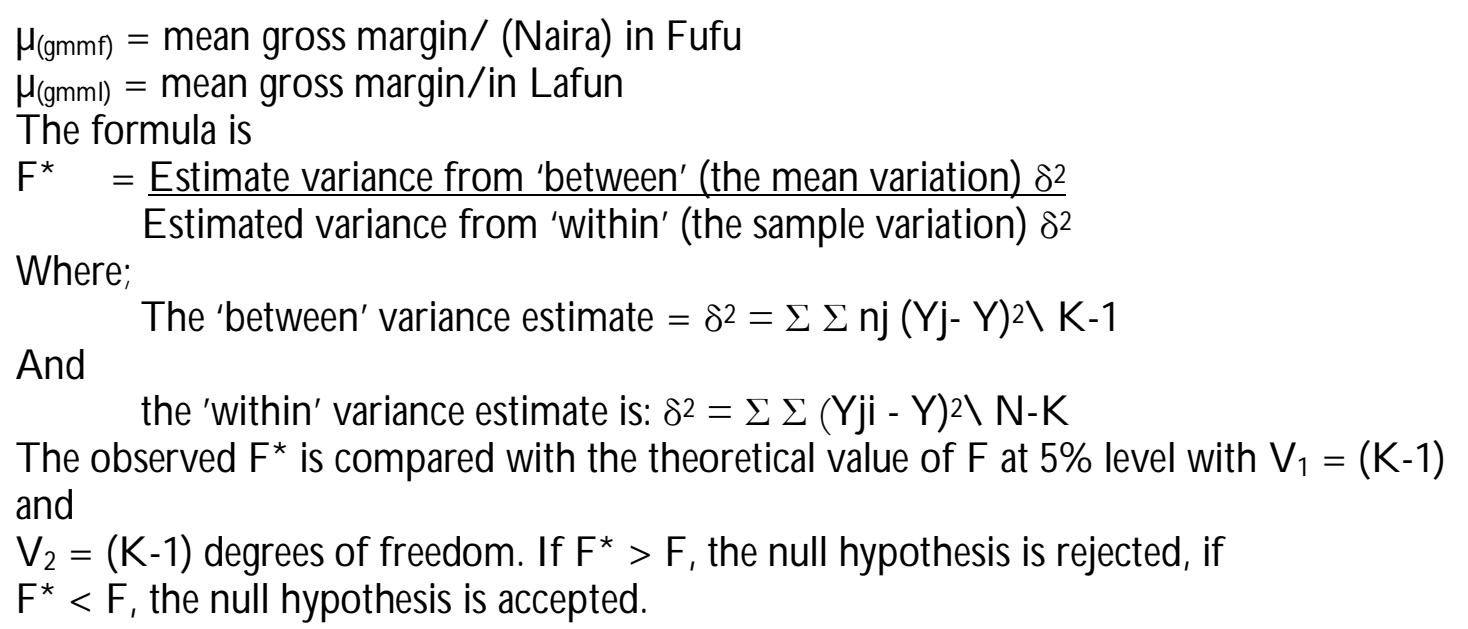

\section{RESULT AND DISCUSSION \\ Socio-E conomic Characteristics of the Sampled Respondents}

Table 1 shows the result of the socioeconomic characteristics of cassava value chain actors considered in the study area. It revealed that the mean age of the cassava value chain actors was 44 years and 38 years for processors and marketers respectively. Also 77.9 percent and 81.2 percent of processors and marketers are aged below 50 years (Table 2). This implies that majority of the farmers are in their active age and this agreed with the findings of (Oluwasola and Alimi, 2008; Anyanwu, 2004). This also informs their skill, ability and wiliness to adopt new innovations and technologies which can be used to transform the cassava industry in the study area. In terms of sex, the study revealed that 15.7 percent are male while 84.3 percent are female for processors of cassava while for cassava marketers 28.3 percent are male and 52.8 percent are female respectively. The result revealed that majority of the actors in cassava value chain in the study area are female and this may be due to the fact that female are predominant in processors and marketers while the male are basically into production of the cassava. In terms of years of experience in the trade, majority of them were very knowledgeable. About $61.9 \%$ of the respondents had at least 6 years of experience in the trade. About $61.9 \%$ of the respondents had at least 6 years of experience in the trade. The study further showed that majority (63.9 percent) of processors and 80.0 percent of marketers have their household size falling between 5 and 8 members with a mean of 6 and 5 household members for processors and marketers respectively. It is expected that the larger household size of both processors and marketers along the value chain should translate to higher output and eventual profit. The result further showed that majority as accounted for both processors (75.0 percent) and marketers (69.4 percent) of cassava are members of a cassava processors and marketers association while 25.0 percent for processors and 30.6 percent for marketers are not member of any poultry farmer's association.

It was also gathered from the study that 59.3 percent and 45.8 percent for the processors and marketers respectively do not have any other source of income other than cassava processing and marketing. Also, the study revealed that 34.4 percent of both processors 
*V. A. ELEG BEDE, A.O. DIPEOLU AND A.M. SHITTU

and marketers are traders. This means that cessing thereby increasing their profit margin they can plough back their returns these along the value chain.

other sources back into the cassava pro-

Table 1: Socio-Economic Characteristics of Respondents in the Study Area

\begin{tabular}{|c|c|c|c|c|c|c|}
\hline & Processors & & Marketers & & Pooled & \\
\hline $\begin{array}{l}\text { Variable } \\
\text { Age group } \\
\text { (years) }\end{array}$ & Frequency & Percentage & Frequency & Percentage & Frequency & Percentage \\
\hline $21-30$ & 21 & 19.4 & 22 & 30.6 & 23.9 & 43 \\
\hline $31-40$ & 30 & 27.8 & 23 & 31.9 & 53 & 29.4 \\
\hline $41-50$ & 29 & 30.7 & 14 & 18.7 & 37 & 29.4 \\
\hline $51-60$ & 17 & 15.7 & 5 & 6.9 & 22 & 12.2 \\
\hline$>60$ & 11 & 10.2 & 0 & 0.0 & 11 & 6.1 \\
\hline Total & 108 & 100.0 & 72 & 100.0 & 180 & 100.0 \\
\hline Mean & & 44 & & 38 & & \\
\hline \multicolumn{7}{|l|}{ Sex } \\
\hline Male & 17 & 15.7 & 34 & 47.2 & 51 & 28.3 \\
\hline Female & 91 & 84.3 & 34 & 47.2 & 129 & 71.7 \\
\hline Total & 108 & 100.0 & 72 & 100.0 & 180 & 100.0 \\
\hline \multicolumn{7}{|l|}{$\begin{array}{l}\text { Position in the } \\
\text { Household }\end{array}$} \\
\hline Child & 8 & 7.4 & 7 & 9.7 & 15 & 8.3 \\
\hline Head & 30 & 27.8 & 32 & 45.8 & 62 & 34.4 \\
\hline Spouse & 70 & 64.8 & 33 & 45.8 & 33 & 57.2 \\
\hline Total & 108 & 100.0 & 72 & 100.0 & 180 & 100.0 \\
\hline \multicolumn{7}{|l|}{$\begin{array}{l}\text { E ducational } \\
\text { Level }\end{array}$} \\
\hline $\begin{array}{l}\text { No Formal Ed- } \\
\text { ucation }\end{array}$ & 6 & 5.6 & 4 & 5.6 & 10 & 5.6 \\
\hline Primary & 37 & 34.3 & 31 & 43.1 & 68 & 37.8 \\
\hline Secondary & 65 & 60.2 & 37 & 51.4 & 102 & 56.7 \\
\hline Total & 108 & 100.0 & 72 & 100.0 & 180 & 100.0 \\
\hline
\end{tabular}

Source: Field Survey, 2019. 
Table 2 shows the description of benefit of members of association, purpose of loan from cooperative society and purpose of loan from other sources is presented in $\mathrm{Ta}$ ble 4 . The result of the study revealed that 42.6 percent and 12.5 percent of the cassava processors and marketers respectively are beneficiary of advisory/technical service while majority (57.4 percent and 87.5 percent) are non-beneficiary. Also, it was further gathered that 46.3 percent of the cassava processors and 36.1 percent of the marketers had access to credit. Similarly, only 14.8 percent and 19.4 percent for the cassava processors and marketers respectively are beneficiary of input needed for carrying out their activities. The beneficiaries of the advisory/ technical service, credit and input are members of association. Therefore, majority of the respondents in the study area could not benefit because they are nonmember of the association. The loan benefitted by the processors and marketers from the cooperative society was used for various activities such as farming and processing. For the processors, 71.3 percent used the loan for processing while 81.9 percent of the marketers also used the loan for processing. O nly 19.4 percent and 13.9 percent for processors and marketers respectively used their loan for farming while 7.3 percent for both processors and marketers do not use their loan for any of the activities. More so, loan realized from other sources such as Agricultural banks and Community bank were also used by the stakeholders for processing and farming. It was discovered that 39.8 percent and 44.4 percent of the cassava processors and marketers respectively use the loan benefitted from these other sources for processing while 27.2 percent of both processors and marketers used similar loan for farming. It was further discovered that only 52.8 percent of the mar- keters had access to less than 20,000 while 0.9 percent and 12.5 percent for processors and marketers respectively had access to between 40001 and 60000 loan. Majority (91.7 percent) of the cassava processors had access to more than 100,000 loans while none of the marketer had access to similar loan.Table 3 shows the results of the budgetary techniques estimated for the cassava products along the value chain for the cassava processors. The analysis is based on data for the cassava product which includes gari, fufu and lafu. The gross margin is the difference between the total revenue and the variable cost. From the result of the study the total variable cost of the cassava product which include gari, fufu and lafu was estimated as N22437.29, N20195.04 and N20203.18 respectively per annum and accounted for percent 98.26, 79.51 and 94.89 respectively of the total cost of the cassava product. It was discovered that the harvesting cost accounted for the highest of the total variable cost for the various cassava products. For the cassava products viz gari, fufu and lafu the harvest cost was estimated as N4158.82, N4600.00 and N4450.33 per annum which accounted for 18.21, 18.11 and 20.90 percent respectively. Roasting cost, sieving cost and washing cost is next to harvesting cost for garri, fufu and lafu respectively and were estimated as N3663.82, N3877.78 and N4450.00 which accounted for 16.04, 15.27 and 20.82 respectively of the total cost. Also the total fixed cost for gari, fufu and lafu was estimated as N398.28, N5204.17, N1088.10 respectively, This shows that variable cost constituted larger proportion of the total cost for all the cassava products. The result further revealed that the revenue from fufu accounted for the highest of the cassava products which gave total revenue of N140658.65 as compared to the other products. 


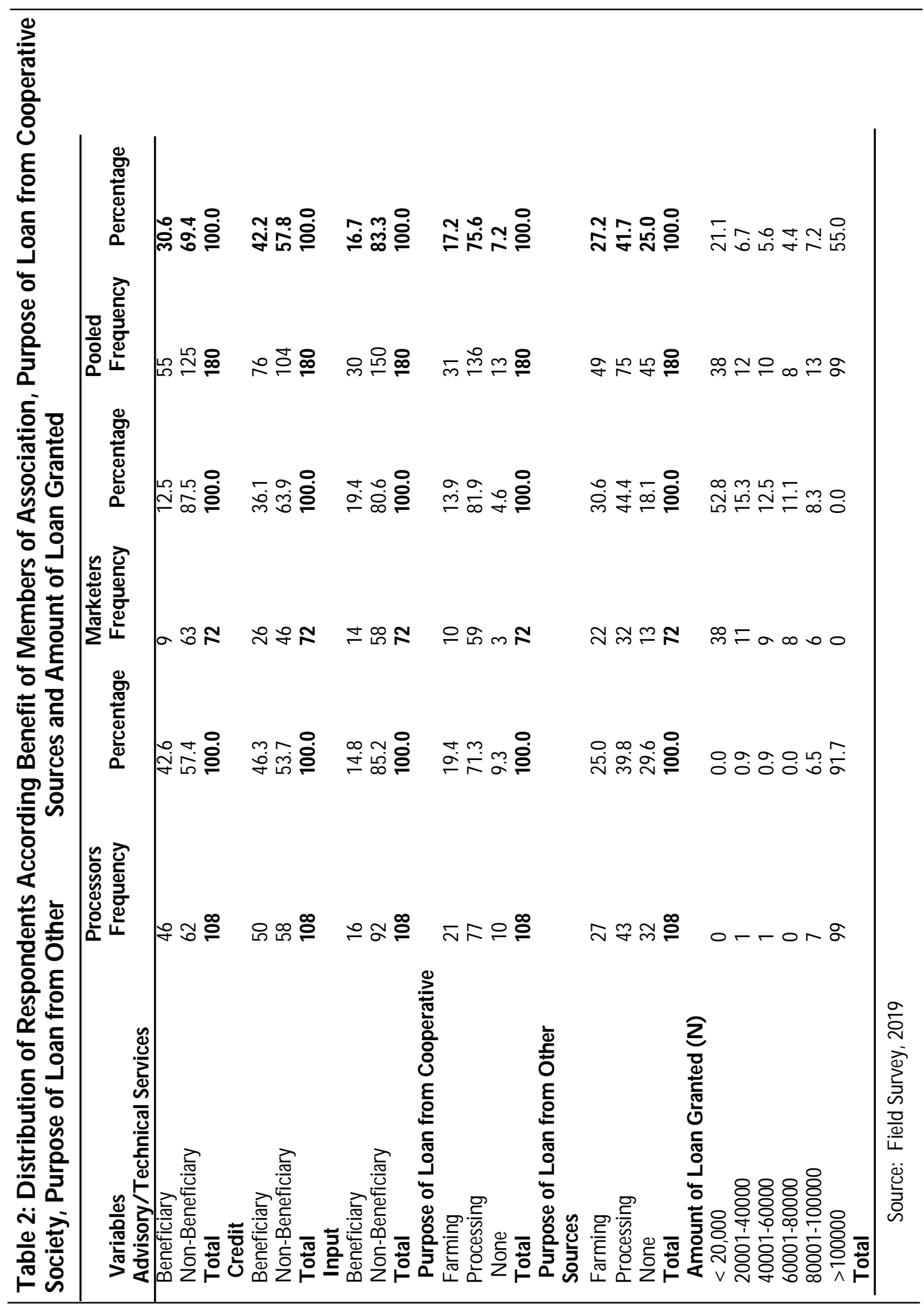

J. Hum. Soc. Sci. Crtv. Arts 2018, 13:75-88 
The result also showed that gross margin is positive for all the cassava products. The value of the gross margin for gari, fufu and lafu was estimated as N35876.13, N120463.61 and N49186.82 respectively per annum. From the result of the gross margin it was discovered that fufu is more profitable along the cassava product value chain when compared to the other products. On the other hand the gross margin for the cassava peel was estimated as N36731.13 with total revenue of N39279.42. The profitability indicator for the cassava products revealed that the return per naira which is the ratio of the total revenue to the total cost was estimated as 2.55, 5.54 and 3.26 respectively for gari, fufu and lafun. This means that for every one naira spent the processor these ratios. The gross margin analysis of the various products and the by-product selected along the cassava value chain in the study area indicated that fufu was more profitable in relation to other cassava products.

Table 5 shows the result of the marketing margin and marketing efficiency of cassava products. The marketing margin is the difference between the selling price and the purchase price of the cassava products and by-product while the net marketing margin is the difference between the marketing margin and the marketing cost. The total marketing cost for gari, fufu and lafun was estimated as $\mathrm{N} 650.23, \quad \mathrm{~N} 7323.35$ and N5249.68 respectively. The transportation cost accounted for the highest percentage for the gari, fufu and lafun with $60.19 \%$, $43.40 \%$ and $58.92 \%$ respectively with a value of N3916.25, N3178.05 and N3093.30 respectively. This might be due to high cost transportation faced by most marketers in transporting their products from the farm gate to the main markets. The packaging cost is next to transportation cost with a value of N1056.88, N2136.25 and N1000.00 for gari, fufu and lafun respectively. This could be as a result of the desire of the marketers to add value to product in order to make it more desirable and acceptable to the final consumers. The marketing margin for gari, fufu and lafun was estimated as N25273.07, N2982.65 and N21453.49 respectively per annum while the net marketing margin was also estimated as N18766.84, N22489.30 and N16203.81 respectively per annum. From the result it was discovered that fufu has the highest marketing margin and net marketing margin. The marketing efficiency which is ratio of net marketing margin and marketing cost for the cassava products was estimated as $74.26 \%, 75.44 \%$ and $75.53 \%$ respectively for gari, fufu and lafun with cassava lafun having the highest marketing efficiency. It can be deduced that fufu has the highest margin and lafun has the highest efficiency along the cassava value chain in comparison with the other cassava products. 
*V. A. ELEGBEDE, A.O. DIPEOLU AND A.M. SHITTU

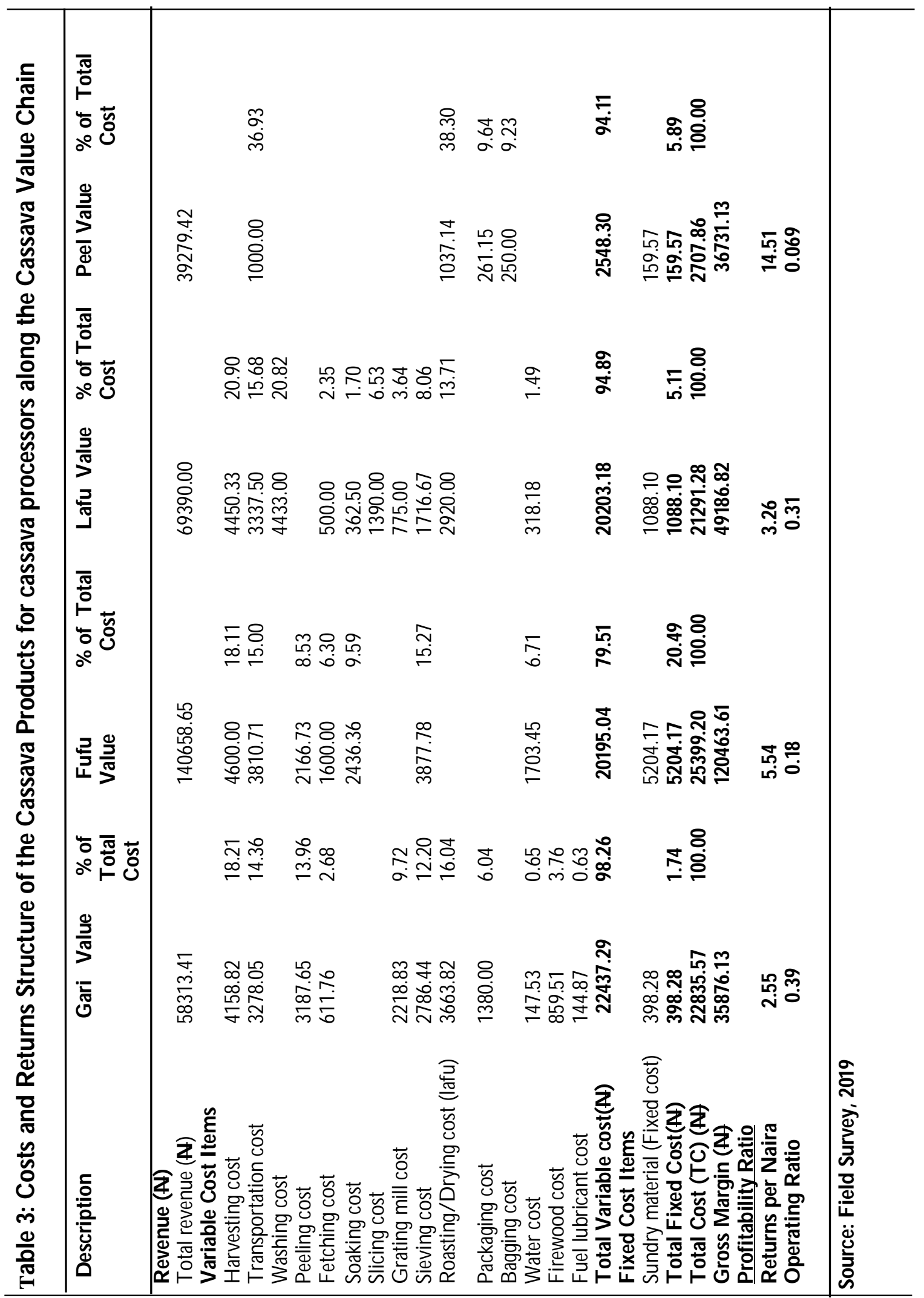

J. Hum. Soc. Sci. Crtv. Arts 2018, 13:75-88 84 


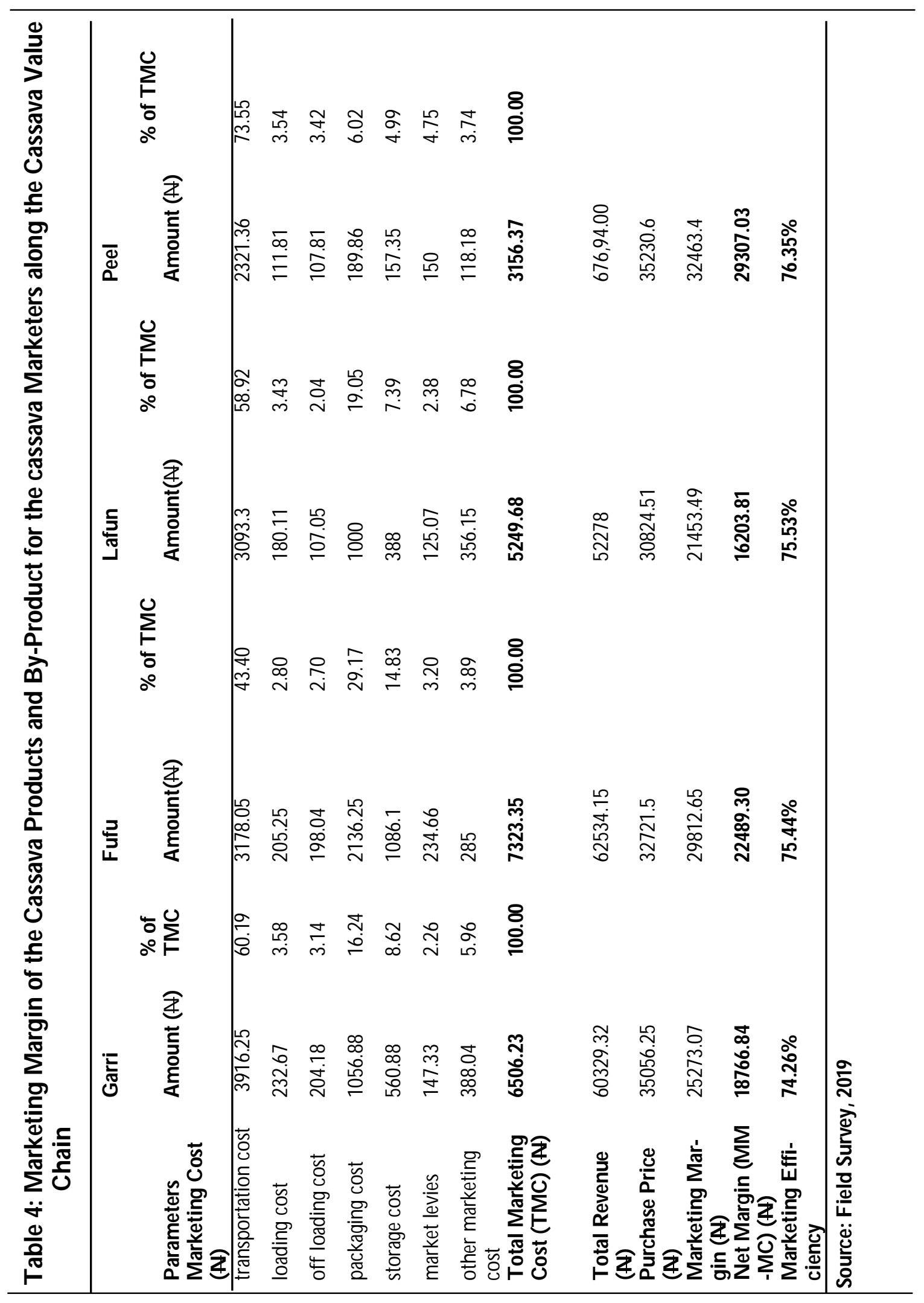

J. Hum. Soc. Sci. Crtv. Arts 2018, 13:75-88 85 
*V.A. ELEGBEDE, A.O.DIPEOLU AND A.M. SHITTU

Table 5 reveals the Measurement of mean states that there is no significant difference Profit difference Cassava Processors and Marketers in the study area. To determine the mean difference between the profit level of the cassava processors and marketers engaging in gari, fufu and lafun processing and marketing in the study area, ANOVA was used to achieve this and the result is presented in Table 5. The null hypothesis between the profit level of cassava processors and cassava marketers in the study area. The result of the F-value revealed that there is significant difference between the Gross margin of the cassava processors and the cassava marketers, as the F-value was significant at 1 percent. Therefore the null hypothesis was rejected.

Table 5: ANOVA test of Difference between the profit level of the cassava processors and cassava marketers

\begin{tabular}{|c|c|c|c|c|c|c|}
\hline $\begin{array}{l}\text { Category } \\
\text { Cassava } \\
\text { Processors }\end{array}$ & $\begin{array}{l}\text { Mean } \\
\text { Squares }\end{array}$ & $\begin{array}{l}\text { Sum of } \\
\text { Squares }\end{array}$ & $\overline{\text { Df }}$ & F-Value & Sig & Decision \\
\hline $\begin{array}{l}\text { Between } \\
\text { G roups }\end{array}$ & $2.178 * 10^{6}$ & $4.357 * 106$ & 3 & 20.616 & 0.00 & ${\text { Reject } \mathrm{H}_{\mathrm{o}}}$ \\
\hline $\begin{array}{l}\text { Within } \\
\text { Groups }\end{array}$ & $6.006 * 10^{5}$ & $4.324 * 10^{6}$ & 108 & & & \\
\hline $\begin{array}{l}\text { Total } \\
\text { Cassava } \\
\text { Marketers }\end{array}$ & & $8.681 * 106$ & 180 & & & \\
\hline $\begin{array}{l}\text { Between } \\
\text { Groups }\end{array}$ & $1.019 * 105$ & $2.0347 * 10^{5}$ & 3 & 24.513 & 0.00 & \\
\hline $\begin{array}{l}\text { Within } \\
\text { Groups }\end{array}$ & $1.257 * 10^{3}$ & $9.054 * 10^{4}$ & 72 & & & \\
\hline Total & & $2.943^{*} 10^{5}$ & 180 & & & \\
\hline
\end{tabular}

Source: Field Survey, 2019

\section{CONCLUSION AND \\ RECOMMENDATION}

The result of the study revealed that majority of Cassava processors and marketers are female. It suggests the willingness of young females to take up employment in cassava processing Also, the mean age of the cassava value chain actors was discovered to be 44 years and 38 years for processors and marketers respectively. Efforts should be made, therefore, to provide all necessary incentives that will encourage more unemployed female youths, especially school leavers, to take up employment in food processing enterprises. The result of the budgetary analysis, Marketing margin and efficiency revealed that fufu is more profitable for both processors and marketers. It is also clear 
from the profit per naira is higher for fufu compare to other cassava products (gari and lafun). Thus, the present study revealed that fufu has performed better along the cassava value chain than other cassava products. Based on findings of this study, the following policy recommendations were advanced to positively bring about improvement in the cassava value chain especially redirecting the interest of the masses and the government to cassava products. This study therefore recommends that processing and marketing of fufu is efficient and its trade is profitable. Also, cassava processors and marketers should form cooperative groups to increase access to credit for higher output and trade of products. Soft loans and credit should be made available to processors and marketers at low interest rate and without collateral so that they can be able to maximise profit generated from the products.

\section{REFERENCES}

Arthur, M.M, Titus, A., Barbara, Z.M. and Hement K.O. 2009. A handbook for the conduct of confined field trials of transgenic cassava in Uganda. Uganda National Council for Science and Technology. Pp 4556.

Ebukiba E. 2010. Economic analysis of cassava production (farming) in Akwaibom State, Agriculture and Biology journal of north AMERICA Pp 1, http:// www.scihub.org/ABJNA

Elegbede, V.A.m Dipeolu, A.O., Shittu A. M. 2018. "Economic Analysis of Cassava Peel Processing and Marketing in O gun State, Nigeria". Proceedings of the $5^{\text {th }} \mathrm{Na}$ tional Conference of Sustainable Livelihoods and D evelopment Network for Africa (SLIDEN AFRICA). 9th to 12th April, pp: 49-56.

FAO 1999. Production Yearbook. FAOSTAT Data Base. (Consulted O ctober, 2008) Food and Agricultural Organisation (FAO), 2006. A CASSAVA Industrial Revolution in Nigeria. FAO Cooperate Document Repository.

Lenis, S.O . L., Gbolagade, B.A., Oyeleke, R.0. 2009. Enhancing the Competitiveness of Agricultural Commodity Chains in Nigeria: Identifying Opportunities with Cassava, Rice, and Maize using a Policy Analysis Matrix (PAM) Framework, Nigeria Strategy Support Program (NSSP) background Paper No. (NSSP) 013 pp 1-4

Nweke, F.T; Spencer, D.S.C. and Lynam, J.K. 2003. The Cassava Transformation: Africa's best-kept secret. International Institute of Tropical Agriculture, Ibadan, Nigeria.

Obadina A.0., Oyewole O.B., Sanni L.0., Tomlins K.I., Westby .A. 2007. Identification of Hazards and Critical Control Points (CCP) for Cassava Fufu Processing in South- West Nigeria.

Odedina, S.A., Odedina, J.N., Ogunkoya, M.0., Ojeniyi, S.0. 2009. Agronomic evaluation of new cassava varieties introduced to farmers in Nigeria, African Crop Science Conference Proceedings, Vol. 9.Pp. 77-80

Onwulalu A.P 2007. Nigeria tackles cassava production, processing and marketing issues.

Sanni, L.0., Onadipe, 0.0., Ilona, P., Mussasy, M.D., Abass, A., Dixon, A.G.O. 2009. Successes and Challenges of Cassava enterprises in West Africa: a case study og Nigeria, Benin and Sierra leone. IITA, Iba- 
*V. A. ELEG BEDE, A.O. DIPEOLU AND A.M. SHITTU

dan, Nigeria. 19 Pp.

mand and Supply among Small scale Farmers

Oluwasola, 0., Alimi. T. 2008.

in Nigeria" O utlook Agric. 37(3):185 - 193.

"D eterminants of Agricultural Credit De-

(Manuscipt reecived 27th August, 2018; accepted 21stJun, 2019). 